\title{
Generic Statins in Cardiovascular Medicine
}

\section{Andrea Feher ${ }^{1}$, Gabriella Pusch², Gabor Harang ${ }^{3}$, Hedvig Komaromy ${ }^{1}$, Laszlo Szapary ${ }^{1}$ and Gergely Feher ${ }^{1 *}$}

${ }^{1}$ Department of Neurology, University of Pecs, Pecs, Hungary

${ }^{2}$ Department of Internal Medicine, Balassa Janos Hospital, Szekszard, Hungary

${ }^{3}$ Department of Surgery, Balassa Janos Hospital, Szekszard, Hungary

\begin{abstract}
Cardiovascular disease is the leading cause of death and disability in Europe. Several large, population-based trials and their meta-analyses have shown the beneficial effects of statins in reducing mortality and cardiovascular morbidity both primary and secondary prevention. Use of generic drugs, which are bioequivalent to brand-name drugs, can help contain prescription drug spending. However, there is concern among patients and physicians that brandname drugs may be clinically superior to generic drugs. The aim of our study was to review the efficacy of generic statin therapy in both primary and secondary vascular prevention.

Treatment with generic statins seem to be safe and quite effective. Lipid parameters should be monitorized, there are class effects in the lipid lowering potency of different drugs. Based on comparism trials, worsening lipid profile was associated with unfavourable outcome. From an economic point of view, society could gain a lot from substituting statin therapy, especially from therapeutic substitution. Moreover, prescribing generic or preferred medications within a therapeutic class seemed to be associated with improvements in adherence to therapy.
\end{abstract}

Keywrds: Statin; Primary prevention; Secondary prevention; Generic substitution; Vascular disease; Atherosclerosis

\section{Introduction}

Cardiovascular disease is the leading cause of death and disability in Europe [1]. Several large, population-based trials and their metaanalyses have shown the beneficial effects of statins in reducing mortality and cardiovascular morbidity both primary and secondary prevention $[1,2]$. Statins have been associated with a variety of pleiotropic effects, including atherosclerotic plaque stabilization, decreased inflammation, improvement in endothelial function, and altered thrombogenicity $[1,2]$.

International clinical guidelines recommend total cholesterol of $<190 \mathrm{mg} /$ dl and low-density lipoprotein (LDL) cholesterol of $<115 \mathrm{mg} /$ $\mathrm{dl}$ as objectives for the general population, and of $<175 \mathrm{mg} / \mathrm{dl}$ and $<100$ $\mathrm{mg} / \mathrm{dl}$ respectively in secondary prevention and diabetes $[3,4]$.

The problem of rising prescription drug costs has emerged as a critical policy issue, straining the budgets of patients and public/ private insurers and directly contributing to adverse health outcomes by reducing adherence to important medications [4-8]. The primary drivers of elevated drug costs are brand-name drugs, which are sold at high prices during a period of patent protection [8]. To control spending, many payers and providers have encouraged substitution of inexpensive bioequivalent generic versions of these drugs, which can legally be marketed by multiple manufacturers after the brand-name manufacturer's market exclusivity period ends [8]. Some physicians and patients have expressed concern that bioequivalent generic and brandname drugs may not be equivalent in their effects on various clinical parameters, including physiological measures such as heart rate or blood pressure, important laboratory measurements, and outcomes such as health system utilization or mortality [8].

The aim of our study was to review the efficacy of generic statin therapy in both primary and secondary vascular prevention.

\section{Statins in primary prevention}

Statins, especially generic statins are widely used in the primary prevention of vascular diseases. On the other hand, the benefitial effects of statins in this population are controversial. Several review and metaanalyses examined the efficacy of statins in primary prevention trials. Results were controversial, the first three published review and meta analysis showed that primary prevention with these drugs provided only small and clinically hardly relevant improvement of cardiovascular morbidity/mortality while secondary prevention provided considerable improvement of cardiovascular morbidity/mortality [9,11] (Table 1).

To clarify the disconcordant results of the above mentioned studies (using strict inclusion-exclusion criteria) including 19 trials (63899 patients) represented a comprehensive meta-analysis of statin therapy for primary prevention and this meta-analysis concluded that statins have a clear role in primary prevention of CVD mortality and major events [12] (Table 1).

Interestingly, a very recent Cochrane analysis showed that limited evidence showed that primary prevention with statins may be cost effective and improve patient quality of life. In the authors' conclusion caution should be taken in prescribing statins for primary prevention among people at low cardiovascular risk [13]. This was also in concordance with recently published articles $[14,15]$.

On the other hand, results are still controversial. There are also numerous meta-analysis showing benefitial effects of statin therapy in primary prevention [16-19] (Table 1, Figure 1). In a very recent meta-analysis which was included in the ESC guidelines showed that

*Corresponding author: Gergely Feher MD, Ph.D, Department of Neurology, University of Pecs, School of Medicine, H-7623 Pecs, Ret u. 2, Hungary, Tel.: +36 72535 900; Fax: +36 72535 911; E-mail: gergely.feher@aok.pte.hu

Received September 05, 2011; Accepted October 24, 2011; Published October 27, 2011

Citation: Feher A, Pusch G, Harang G, Komaromy H, Szapary L, et al. (2011) Generic Statins in Cardiovascular Medicine. J Bioequiv Availab S2. doi:10.4172/ jbb.S2-003

Copyright: () 2011 Feher A, et al. This is an open-access article distributed under the terms of the Creative Commons Attribution License, which permits unrestricted use, distribution, and reproduction in any medium, provided the original author and source are credited. 
Citation: Feher A, Pusch G, Harang G, Komaromy H, Szapary L, et al. (2011) Generic Statins in Cardiovascular Medicine. J Bioequiv Availab S2. doi:10.4172/jbb.S2-003

Page 2 of 8

\begin{tabular}{|c|c|c|c|}
\hline Study & Population & Results & Conclusion \\
\hline Vrecer et al. [9] & $\begin{array}{l}\text { Data from } 15 \text { trials with } \\
63,410 \text { participants and } \\
\text { mean duration of treatment } \\
\text { of } 3.6 \text { years, were included } \\
\text { in this overview. }\end{array}$ & $\begin{array}{l}\text { Overall (primary and secondary studies) statin therapy significantly } \\
\text { reduces relative risk of coronary events (RR, } 0.73,95 \% \mathrm{Cl}, 0.68,0.77,{ }^{*} \mathrm{p} \\
<0.0001) \text {, relative risk of cardiovascular disease mortality }(\mathrm{RR}, 0.78,95 \% \\
\left.\mathrm{Cl}, 0.73,0.84,{ }^{*} \mathrm{p}<0.0001\right) \text {, relative risk of non-fatal stroke }(\mathrm{RR}, 0.74,95 \% \\
\left.\mathrm{Cl}, 0.67,0.82,{ }^{*} \mathrm{p}<0.0001\right) \text {, relative risk of total (fatal and non-fatal) stroke } \\
\left(\mathrm{RR}, 0.77,95 \% \mathrm{Cl}, 0.70,0.84,{ }^{*} \mathrm{p}<0.001\right) \text { and relative risk of all-cause } \\
\text { death }\left(\mathrm{RR}, 0.85,95 \% \mathrm{Cl}, 0.81,0.89,{ }^{*} \mathrm{p}<0.0001\right) \text {. There was a slight and } \\
\text { insignificant reduction of relative risk in non-cardiovascular mortality (RR, } \\
0.94,95 \% \mathrm{Cl}, 0.86,1.03, \mathrm{p}=0.1677) \text { and fatal strokes (RR, } 0.86,95 \% \mathrm{Cl} \text {, } \\
0.70,1.07, \mathrm{p}=0.1912) .\end{array}$ & $\begin{array}{l}\text { While secondary prevention with } \\
\text { statins provided considerable } \\
\text { improvement of cardiovascular } \\
\text { morbidity / mortality, primary } \\
\text { prevention with statins provides } \\
\text { only small and clinically hardly } \\
\text { relevant improvement of } \\
\text { cardiovascular morbidity/mortality. }\end{array}$ \\
\hline $\begin{array}{l}\text { Thavendiranathan } \\
\text { et al. [10] }\end{array}$ & $\begin{array}{l}\text { Seven trials with } 42,848 \\
\text { patients were included. } \\
\text { Ninety percent had no } \\
\text { history of CV disease. } \\
\text { Mean follow-up was } 4.3 \\
\text { years. }\end{array}$ & $\begin{array}{l}\text { Statin therapy reduced the RR of major coronary events, major } \\
\text { cerebrovascular events, and revascularizations by } 29.2 \%(95 \% \mathrm{Cl}, 16.7 \%- \\
39.8 \%)(\mathrm{P}<.001), 14.4 \%(95 \% \mathrm{Cl}, 2.8 \%-24.6 \%)(\mathrm{P}=.02) \text {, and } 33.8 \%(95 \% \\
\mathrm{Cl}, 19.6 \%-45.5 \%)(\mathrm{P}<.001) \text {, respectively. Statins produced a nonsignificant } \\
22.6 \% \mathrm{RR} \text { reduction in coronary heart disease mortality }(95 \% \mathrm{Cl}, 0.56-1.08) \\
(\mathrm{P}=.13) . \text { No significant reduction in overall mortality }(\mathrm{RR}, 0.92[95 \% \mathrm{Cl}, \\
0.84-1.01])(\mathrm{P}=.09) \text { or increases in cancer or levels of liver enzymes or } \\
\text { creatine kinase were observed. }\end{array}$ & $\begin{array}{l}\text { In patients without CV disease, } \\
\text { statin therapy decreases the } \\
\text { incidence of major coronary and } \\
\text { cerebrovascular events and } \\
\text { revascularizations but not coronary } \\
\text { heart disease or overall mortality. }\end{array}$ \\
\hline Ward et al. [11] & $\begin{array}{l}\text { Thirty-one randomised } \\
\text { studies were identified that } \\
\text { compared a statin with } \\
\text { placebo or with another } \\
\text { statin, and reported clinical } \\
\text { outcomes. }\end{array}$ & $\begin{array}{l}\text { Meta-analysis of the available data from the placebo-controlled studies } \\
\text { indicates that, in patients with, or at risk of, CVD, statin therapy is associated } \\
\text { with a reduced relative risk of all cause mortality, cardiovascular mortality, } \\
\text { CHD mortality and fatal myocardial infarction (MI), but not of fatal stroke. It } \\
\text { is also associated with a reduced relative risk of morbidity [non-fatal stroke, } \\
\text { non-fatal MI, transient ischaemic attack (TIA), unstable angina] and of } \\
\text { coronary revascularisation. }\end{array}$ & $\begin{array}{l}\text { The cost-effectiveness modelling } \\
\text { presented here has shown that } \\
\text { statin therapy in secondary } \\
\text { prevention is likely to be considered } \\
\text { cost-effective while in primary } \\
\text { prevention, the cost-effectiveness } \\
\text { ratios are dependent on the level of } \\
\text { CHD risk and age, }\end{array}$ \\
\hline Mills et al. [12] & $\begin{array}{l}\text { They included } 20 \\
\text { randomized clinical trials. }\end{array}$ & 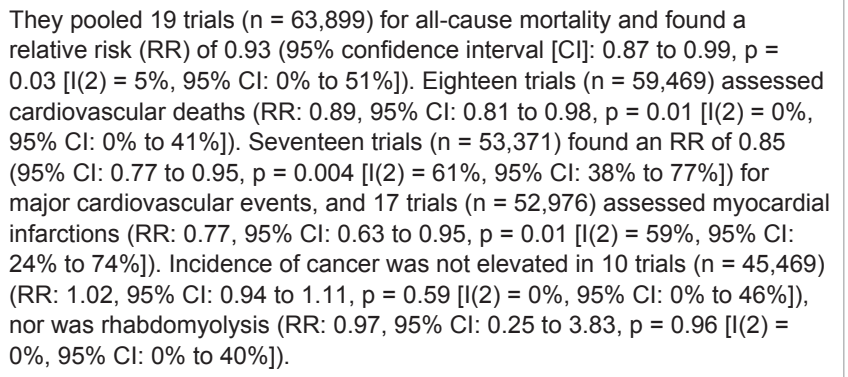 & $\begin{array}{l}\text { Statins have a clear role in primary } \\
\text { prevention of CVD mortality and } \\
\text { major events. }\end{array}$ \\
\hline Taylor et al. [13] & $\begin{array}{l}\text { Fourteen randomised } \\
\text { control trials ( } 16 \text { trial arms; } \\
34,272 \text { participants) were } \\
\text { included. }\end{array}$ & $\begin{array}{l}\text { Eleven trials recruited patients with specific conditions (raised lipids, } \\
\text { diabetes, hypertension, microalbuminuria). All-cause mortality was reduced } \\
\text { by statins (RR } 0.83,95 \% \mathrm{Cl} 0.73 \text { to } 0.95 \text { ) as was combined fatal and non- } \\
\text { fatal CVD endpoints (RR } 0.70,95 \% \mathrm{Cl} 0.61 \text { to } 0.79 \text { ). Benefits were also } \\
\text { seen in the reduction of revascularisation rates (RR } 0.66,95 \% \mathrm{Cl} 0.53 \text { to } \\
0.83 \text { ). Total cholesterol and LDL cholesterol were reduced in all trials but } \\
\text { there was evidence of heterogeneity of effects. There was no clear evidence } \\
\text { of any significant harm caused by statin prescription or of effects on patient } \\
\text { quality of life. }\end{array}$ & $\begin{array}{l}\text { Although reductions in all-cause } \\
\text { mortality, composite endpoints } \\
\text { and revascularisations were found } \\
\text { with no excess of adverse events, } \\
\text { there was evidence of selective } \\
\text { reporting of outcomes, failure to } \\
\text { report adverse events and inclusion } \\
\text { of people with cardiovascular } \\
\text { disease. Only limited evidence } \\
\text { showed that primary prevention } \\
\text { with statins may be cost effective } \\
\text { and improve patient quality of } \\
\text { life. Caution should be taken in } \\
\text { prescribing statins for primary } \\
\text { prevention among people at low } \\
\text { cardiovascular risk. }\end{array}$ \\
\hline Ray et al. [14] & $\begin{array}{l}\text { Data were available on } \\
65,229 \text { participants followed } \\
\text { for approximately } 244,000 \\
\text { person-years, during which } \\
2793 \text { deaths occurred. }\end{array}$ & $\begin{array}{l}\text { The use of statins in this high-risk primary prevention setting was not } \\
\text { associated with a statistically significant reduction (risk ratio, } 0.91 ; 95 \% \\
\text { confidence interval, } 0.83-1.01 \text { ) in the risk of all-cause mortality. There was } \\
\text { no statistical evidence of heterogeneity among studies }(\mathrm{I}(2)=23 \% ; 95 \% \\
\text { confidence interval, } 0 \%-61 \%[\mathrm{P}=.23] \text { ). }\end{array}$ & $\begin{array}{l}\text { This literature-based meta-analysis } \\
\text { did not find evidence for the benefit } \\
\text { of statin therapy on all-cause } \\
\text { mortality in a high-risk primary } \\
\text { prevention set-up. }\end{array}$ \\
\hline Brugts et al. [18] & $\begin{array}{l}10 \text { trials enrolled a total of } \\
70388 \text { people, of whom } \\
23681(34 \%) \text { were women } \\
\text { and } 16078(23 \%) \text { had } \\
\text { diabetes mellitus. Mean } \\
\text { follow-up was } 4.1 \text { years. }\end{array}$ & $\begin{array}{l}\text { Treatment with statins significantly reduced the risk of all cause mortality } \\
\text { (odds ratio } 0.88,95 \% \text { confidence interval } 0.81 \text { to } 0.96 \text { ), major coronary } \\
\text { events }(0.70,0.61 \text { to } 0.81 \text { ), and major cerebrovascular events }(0.81,0.71 \text { to } \\
0.93 \text { ). No evidence of an increased risk of cancer was observed. There was } \\
\text { no significant heterogeneity of the treatment effect in clinical subgroups. }\end{array}$ & $\begin{array}{l}\text { In patients without established } \\
\text { cardiovascular disease but } \\
\text { with cardiovascular risk factors, } \\
\text { statin use was associated with } \\
\text { significantly improved survival and } \\
\text { large reductions in the risk of major } \\
\text { cardiovascular events. }\end{array}$ \\
\hline
\end{tabular}

Table 1: Primary prevention meta-analysis with statins. 
Citation: Feher A, Pusch G, Harang G, Komaromy H, Szapary L, et al. (2011) Generic Statins in Cardiovascular Medicine. J Bioequiv Availab S2. doi:10.4172/jbb.S2-003

Page 3 of 8

further reductions in LDL cholesterol safely produce definite further reductions in the incidence of heart attack, of revascularisation, and of ischaemic stroke, with each $1.0 \mathrm{mmol} / \mathrm{L}$ reduction reducing the annual rate of these major vascular events by just over a fifth. There was no evidence of any threshold within the cholesterol range studied, suggesting that reduction of LDL cholesterol by $2-3 \mathrm{mmol} / \mathrm{L}$ would reduce risk by about $40-50 \%$ [20]. The benefitial results can be seen in primary prevention populations (Figure 2 )

\section{Generic statins on primary prevention}

Some physicians and patients have expressed concern that bioequivalent generic and brandname drugs may not be equivalent in their effects on various clinical parameters, including physiological measures such as heart rate or blood pressure, important laboratory measurements, and outcomes such as health system utilization or mortality [8]. In a systematic review and meta-analysis studies compared generic and brand-name cardiovascular drugs using clinical efficacy and safety end points were collected. The authors also separately identified editorials addressing generic substitution. They concluded that evidence did not support the notion that brand-name drugs used in cardiovascular disease were superior to generic drugs, a substantial number of editorials counselled against the interchangeability of generic drugs [8].

Only a few head-to-head comparism could be found. The above mentioned article included two generic sattin studies (based on simvastatin). Wiwanitkit et al. [21] conducted a randomized crossover study in Thailand comparing generic and brand simvastatin. Their study demonstrated no significant differences in the therapeutic effect and safety between the generic and original simvastatin products [21]. The study of Assawawitoontip et al. [22] led to the same result.

In their study, Kim et al. [23] examined the efficacy and tolerability of a generic and a branded formulation of atorvastatin $20 \mathrm{mg} / \mathrm{d}$ in hypercholesterolemic Korean adults at high risk for cardiovascular disease. A total of 211 patients completed the study (50.7\% male; $100 \%$ Asian; mean [SD] age, 61.7 [9.2] years) (106 patients in the group that received the generic formulation and 105 patients in the group that received the branded formulation). LDL-C concentrations were reduced from the baseline by $44 \%$ and $46 \%$ after 8 weeks of treatment with the generic and branded formulations, respectively $(\mathrm{P}=\mathrm{NS})$.

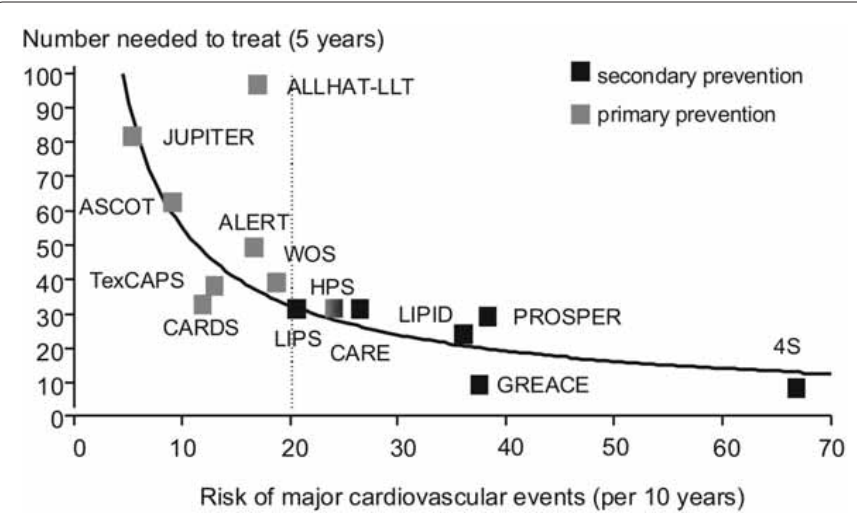

Figure 1: Relationship between the number of persons to prevent one major coronary event (number needed to treat NNT, based on 5 years) and "global" cardiovascular risk in statin trials (expressed as the rate of fatal and non-fatal events per 10 years), Taken from Ref [19].

\begin{tabular}{|c|c|c|c|c|c|}
\hline & \multicolumn{2}{|c|}{ Events (\% per annum) } & \multirow{2}{*}{\multicolumn{2}{|c|}{$\begin{array}{l}\mathrm{RR}(\mathrm{Cl}) \text { per } 1 \mathrm{mmol} / \mathrm{L} \\
\text { reduction in LDL-C }\end{array}$}} & \multirow{2}{*}{$\begin{array}{l}\text { Heterogeneity/ } \\
\text { trend test }\end{array}$} \\
\hline & Statin/more & Control/less & & & \\
\hline \multicolumn{6}{|c|}{ Previous vascular disease } \\
\hline CHD & $8395(4.5 \%) 1$ & $10123(5 \cdot 6 \%)$ & & $0.79(0.76-0.82)$ & \multirow{3}{*}{$\begin{array}{l}x_{2}^{2}=2 \cdot 28 \\
(p=0.3)\end{array}$} \\
\hline Non-CHD vascular & $674(3-1 \%)$ & $802(3.7 \%)$ & & $0.81(0.71-0.92)$ & \\
\hline None & $1904(1 \cdot 4 \%)$ & $2425(1.8 \%)$ & & $0.75(0.69-0.82)$ & \\
\hline \multicolumn{6}{|l|}{ Diabetes } \\
\hline Type 1 diabetes & $145(4 \cdot 5 \%)$ & $192(6.0 \%)-$ & & $0.77(0.58-1.01)$ & \multirow{3}{*}{$\begin{array}{l}x_{2}^{2}=0.41 \\
(\mathrm{p}=0.8)\end{array}$} \\
\hline Type 2 diabetes & $2494(4 \cdot 2 \%)$ & $2920(5.1 \%)$ & & $0.80(0.74-0.86)$ & \\
\hline No diabetes & $8272(3 \cdot 2 \%) 1$ & $10163(4.0 \%)$ & & $0.78(0.75-0.81)$ & \\
\hline \multicolumn{6}{|l|}{ Sex } \\
\hline Male & $8712(3.5 \%)$ & $10725(4 \cdot 4 \%)$ & & $0.77(0.74-0.80)$ & \multirow{2}{*}{$\begin{array}{l}\chi_{1}^{2}=4 \cdot 13 \\
(p=0.04)\end{array}$} \\
\hline Female & $2261(2 \cdot 5 \%)$ & $2625(2 \cdot 9 \%)$ & & $0.83(0.76-0.90)$ & \\
\hline \multicolumn{6}{|l|}{ Age (years) } \\
\hline 565 & $6056(2.9 \%)$ & $7455(3.6 \%)$ & & $0.78(0.75-0.82)$ & \multirow{3}{*}{$\begin{array}{l}\chi_{1}^{2}=0 \cdot 70 \\
(p=0 \cdot 4)\end{array}$} \\
\hline$>65$ to $\leq 75$ & $4032(3.7 \%)$ & $4908(4 \cdot 6 \%)$ & & $0.78(0.74-0.83)$ & \\
\hline$>75$ & $885(4.8 \%)$ & $987(5.4 \%)$ & & $0.84(0.73-0.97)$ & \\
\hline \multicolumn{6}{|c|}{ Treated hypertension } \\
\hline Yes & $6176(3-7 \%)$ & $7350(4-5 \%)$ & & $0.80(0.76-0.84)$ & \multirow{2}{*}{$\begin{array}{l}\chi_{1}^{2}=2 \cdot 67 \\
(\mathrm{p}=0.1)\end{array}$} \\
\hline No & $4543(2 \cdot 7 \%)$ & $5707(3.5 \%)$ & & $0.76(0.72-0.80)$ & \\
\hline \multicolumn{6}{|c|}{ Systolic blood pressure $(\mathrm{mm} \mathrm{Hg})$} \\
\hline$<140$ & $5470(3.2 \%)$ & $6500(3 \cdot 8 \%)$ & & $0.80(0.77-0.85)$ & \multirow{3}{*}{$\begin{array}{l}\chi_{1}^{2}=1 \cdot 19 \\
(p=0 \cdot 3)\end{array}$} \\
\hline$\geq 140$ to $<160$ & $3145(3.0 \%)$ & $4049(3.9 \%)$ & & $0.75(0.70-0.80)$ & \\
\hline$\geq 160$ & $2067(3-6 \%)$ & $2473(4.5 \%)$ & & $0.79(0.73-0.85)$ & \\
\hline \multicolumn{6}{|c|}{ Diastolic blood pressure $(\mathrm{mm} \mathrm{Hg})$} \\
\hline$<80$ & $4558(3.5 \%)$ & $5306(4 \cdot 2 \%)$ & & $0.81(0.76-0.85)$ & \multirow{3}{*}{$\begin{array}{l}x_{1}^{2}=2.01 \\
(p=0.2)\end{array}$} \\
\hline$\geq 80$ to $<90$ & $3670(3-0 \%)$ & $4587(3.8 \%)$ & & $0.77(0.73-0.82)$ & \\
\hline$\geq 90$ & $2452(3.0 \%)$ & $3128(3.9 \%)$ & & $0.77(0.72-0.82)$ & \\
\hline \multicolumn{6}{|c|}{ Body-mass index $\left(\mathrm{kg} / \mathrm{m}^{2}\right)$} \\
\hline$<25$ & $3030(3-0 \%)$ & $3688(3 \cdot 7 \%)$ & & $0.79(0.74-0.84)$ & \multirow{3}{*}{$\begin{array}{l}\chi_{1}^{2}=0 \cdot 10 \\
(\mathrm{p}=0.8)\end{array}$} \\
\hline$\geq 25$ to $<30$ & $5033(3 \cdot 3 \%)$ & $6125(4 \cdot 1 \%)$ & & $0.78(0.74-0.82)$ & \\
\hline$\geq 30$ & $2732(3.3 \%)$ & $3331(4 \cdot 1 \%)$ & & $0.78(0.73-0.84)$ & \\
\hline \multicolumn{6}{|c|}{ HDL cholesterol (mmol/L) } \\
\hline$\leq 1.0$ & $5032(4.0 \%)$ & $6165(5.0 \%)$ & & $0.78(0.75-0.82)$ & \multirow{3}{*}{$\begin{array}{l}\chi_{1}^{2}=0.15 \\
(p=0.7)\end{array}$} \\
\hline$>1.0$ to $\leq 1.3$ & $3656(3.1 \%)$ & $4452(3.9 \%)$ & & $0.77(0.73-0.82)$ & \\
\hline$>1 \cdot 3$ & $2199(2 \cdot 4 \%)$ & $2633(2 \cdot 9 \%)$ & & $0.80(0.74-0.87)$ & \\
\hline \multicolumn{6}{|l|}{ Smoking status } \\
\hline Current smokers & $2268(3.6 \%)$ & $2896(4.7 \%)$ & & $0.78(0.73-0.84)$ & \multirow{2}{*}{$\begin{array}{l}\chi_{1}^{2}=0-02 \\
(\mathrm{p}=0.9)\end{array}$} \\
\hline Non-smokers & $8703(3-1 \%)$ & $10452(3-9 \%)$ & & $0.78(0.75-0.82)$ & \\
\hline \multicolumn{6}{|c|}{ Estimated GFR $\left(\mathrm{mL} / \mathrm{min}\right.$ per $\left.1.73 \mathrm{~m}^{2}\right)$} \\
\hline$<60$ & $2712(4-1 \%)$ & $3354(5-1 \%)$ & & $0.77(0.72-0.83)$ & \\
\hline$\geq 60$ to $<90$ & $6161(3-2 \%)$ & $7540(4 \cdot 0 \%)$ & & $0.78(0.75-0.82)$ & $x_{1}^{2}=0.02$ \\
\hline 290 & $1315(2.5 \%)$ & $1571(3.0 \%)$ & & $0.77(0.69-0.85)$ & $(p=0.9)$ \\
\hline Total & $10973(3.2 \%) 1$ & $13350(4 \cdot 0 \%)$ & 1 & $0.78(0.76-0.80)$ & \\
\hline $99 \%$ or & & 0.5 & ${ }_{0.75}^{1}$ & $\overrightarrow{1}_{1.25}$ & \\
\hline
\end{tabular}

Figure 3: Effects on major vascular events per $1.0 \mathrm{mmol} / \mathrm{L}$ reduction in LDL cholesterol, by baseline prognostic factors, Taken from Ref [20].

The percentage changes from baseline to study end in HDL-C, TC TG, apo A1, apo B, and hsCRP concentrations and sdLDL fraction the proportions of patients who achieved the LDL-C goal between the 2 groups did not reach statistical significance. The most commonly reported events were hepatobiliary laboratory abnormality $(1.7 \%)$, general somatic discomfort (1.7\%), and epigastric pain $(0.8 \%)$ in the group that received the generic formulation, and myalgia $(1.7 \%)$, epigastric pain $(0.9 \%)$, and elevation of creatinine phosphokinase $(0.9 \%)$ in the group that received the branded formulation. No serious adverse events were reported in either group [23].

In a Chinese study the efficacy and safety of two generic forms of $10 \mathrm{mg}$ atorvastatin tablets were studied compared to the reference product [24]. This was a single-dose, randomized-sequence, openlabel, 2-period crossover study with a 2-week washout period between doses. Healthy Chinese males (study population: 46) were randomly assigned to receive $20 \mathrm{mg}$ of either the test or reference formulation, and 13 blood samples were obtained over a 48-hour interval. Plasma concentrations of parent atorvastatin and ortho-hydroxy-atorvastatin (primary active metabolite) were simultaneously determined using a validated liquid chromatography-isotopic dilution mass spectrometry 
method. Pharmacokinetic parameters, including $\mathrm{C}(\max ), \mathrm{T}(\max )$, $\mathrm{t}((1 / 2))$, AUC(0-t), and AUC(0-infinity)), were calculated. The mean values of $\mathrm{C}(\max ), \operatorname{AUC}(0-\mathrm{t})$, and $\mathrm{AUC}(0$-infinity)) for the test and reference formulations of atorvastatin $(8.78$ and $10.76 \mathrm{ng} / \mathrm{mL}, 38.22$ and $40.02 \mathrm{ng} / \mathrm{mL} / \mathrm{h}, 42.73$ and $44.51 \mathrm{ng} / \mathrm{mL} / \mathrm{h}$, respectively) and ortho-hydroxy-atorvastatin $(5.78$ and $5.77 \mathrm{ng} / \mathrm{mL}, 47.32$ and $48.47 \mathrm{ng} /$ $\mathrm{mL} / \mathrm{h}, 52.36$ and $53.14 \mathrm{ng} / \mathrm{mL} / \mathrm{h}$ ) were not significantly different. The $90 \%$ CIs for natural log-transformed ratios of $\mathrm{C}(\max ), \mathrm{AUC}(0-\mathrm{t})$, and AUC(0-infinity)) of both atorvastatin (0.73-0.91, 0.92-1.02, and 0.911.01 , respectively) and ortho-hydroxy-atorvastatin (0.83-1.05, 0.921.02 , and $0.93-1.02$ ) were within the bioequivalence acceptance limits. Three subjects (6.5\%) reported a total of 4 mild AEs (1 abdominal discomfort and 3 venipuncture syncope), which were not considered to be associated with administration of the study drug. This singledose $(20 \mathrm{mg})$ study found that the test and reference formulations of atorvastatin calcium $10-\mathrm{mg}$ tablet met the regulatory definition for assuming bioequivalence in these healthy fasted male volunteers. Both formulations were generally well tolerated in the population studied.

These studies suggest the boiequivalance of generic statins. Despite of their larger use, several recent cost-effectiveness analysis showed the superiority of brand statins in reaching the target lipid levels in different risk categories.

In a Canadian study compared the costeffectiveness of atorvastatin and generic simvastatin in terms of annual drug cost per patient treated to Canadian LDL-C targets. It was conducted from the perspective of the Canadian provincial drug-reimbursement plans. In this hypothetical cohort of 1000 dyslipidemic patients, treatment with atorvastatin would allow achievement of LDL-C targets in more patients than treatment with simvastatin, at an annual incremental cost of $\$ 1088$ per additional patient treated to target [25]. Recently, the costeffectiveness of rosuvastatin have been shown in several economical studies above generic substitutions [26-28].

In general, from an economic point of view, society could gain a lot from substituting statin therapy, especially from therapeutic substitution [29]. Moreover, prescribing generic or preferred medications within a therapeutic class was associated with improvements in adherence to therapy as recently has been shown by Shrank and his collegues [30]. Switching the brand statin to an equivalent dose of generic statin (maybe from another class) can be associated with no change in lipid control [31].

At last, randomized controlled trial data, an internally validated vascular disease model, and US costs of statin therapy and other medical care were used to project lifetime risks of vascular events and evaluate the cost-effectiveness of $40 \mathrm{mg}$ simvastatin daily. This analysis suggested that treatment with generic simvastatin appears to be costeffective for a much wider population in the United States than that recommended by current guidelines [32].

\section{Statins in secondary prevention}

The role of statins in the secondary prevention of vascular events is well established (Figure 1 and 2). In the case of periperal arterial disease a Cochrane meta-analysis were carried out in 2007 [33]. Eighteen trials were included, involving a total of 10,049 participants. Trials differed considerably in their inclusion criteria, outcomes measured, and type of lipid-lowering therapy used. Only one trial (PQRST) reported a detrimental effect of active treatment on blood lipid/lipoprotein levels. The pooled results from all eligible trials indicated that lipid-lowering therapy had no statistically significant effect on overall mortality (Odds Ratio (OR) 0.86; 95\% Confidence Interval (CI) 0.49 to 1.50) or on total cardiovascular events (OR $0.8 ; 95 \%$ CI 0.59 to 1.09 ). However, subgroup analysis which excluded PQRST showed that lipid-lowering therapy significantly reduced the risk of total cardiovascular events (OR 0.74; CI 0.55 to 0.98 ). This was primarily due to a positive effect on total coronary events (OR $0.76 ; 95 \%$ CI 0.67 to 0.87 ). Greatest evidence of effectiveness came from the use of simvastatin in people with a blood cholesterol $>/=3.5 \mathrm{mmol} /$ litre (HPS). Pooling of the results from several small trials on a range of different lipid-lowering agents indicated an improvement in total walking distance (Weighted Mean Difference (WMD) 152 m; 95\% CI 32.11 to 271.88) and painfree walking distance (WMD $89.76 \mathrm{~m}$; 95\% CI 30.05 to 149.47 ) but no significant impact on ankle brachial index (WMD 0.04; 95\% CI -0.01 to 0.09 ). At the moment, statins seem to be the most effient drugs for improving walking distance in this population [34].

Meta-analysis of randomised trials of statins in combination with other preventive strategies, including 165792 individuals, showed that each $1 \mathrm{mmol} / \mathrm{L}(39 \mathrm{mg} / \mathrm{dL})$ decrease in LDL cholesterol equates to a reduction in relative risk for stroke of $21.1 \%$ (95\% CI $6.3-33.5$, $\mathrm{p}=0.009$ ). In secondary prevention of non-cardioembolic stroke, intense reduction of LDL cholesterol by statins also significantly reduced the risk of recurrent stroke (relative risk 0.84, 0.71-0.99, $\mathrm{p}=0.03)$ and major cardiovascular events $(0.80,0.69-0.92, \mathrm{p}=0.002)$. Future directions include assessment of a target LDL cholesterol concentration of less than $1.8 \mathrm{mmol} / \mathrm{L}(70 \mathrm{mg} / \mathrm{dL})$, the effects of triglyceride-lowering therapy alone or in combination with statins, and the effects of treatments to raise HDL cholesterol concentrations [35].

In the case of coronary heart disease a meta analysis of 76 RCTs involving 170,255 participants was carried out. Statin therapy reduced all-cause mortality, Relative Risk (RR) 0.90 [95\% confidence interval (CI) 0.86-0.94, P $\leq 0.0001, \mathrm{I}(2)=17 \%]$; cardiovascular disease (CVD) mortality (RR $0.80,95 \%$ CI $0.74-0.87, \mathrm{P}<0.0001, \mathrm{I}(2)=27 \%$ ); fatal myocardial infarction (MI) (RR 0.82, 95\% CI 0.75-0.91, $\mathrm{P}<0.0001$, $\mathrm{I}(2)=21 \%$ ); non-fatal MI (RR 0.74, 95\% CI 0.67-0.81, P $\leq 0.001$, $\mathrm{I}(2)=45 \%)$; revascularization (RR $0.76,95 \%$ CI $0.70-0.81, \mathrm{P} \leq 0.0001)$; and a composite of fatal and non-fatal strokes $(0.86,95 \%$ CI 0.78-0.95, $\mathrm{P}=0.004, \mathrm{I}(2)=41 \%)$. Adverse events were generally mild, but 17 RCTs reported on increased risk of development of incident diabetes [Odds Ratio (OR) 1.09; 95\% CI 1.02-1.17, P=0.001, I(2)=11\%]. Studies did not yield important differences across populations. The authors could not find not find any differing treatment effects between statins [36].

\section{Generic statins in secondary prevention}

Generic switcing is a cost-saving method, but associated with worsening lipid profile. In a recent study Tunceli et al. identified 18,061 patients who, between September 1, 2004 and October 31, 2008, were either switched from or remained on their initial high-efficacy LDL-C lowering therapy: ezetimibe/simvastatin fixed-dose combination $(\mathrm{E} / \mathrm{S})$, rosuvastatin, or atorvastatin. The difference in percent change in LDL-C levels from baseline were 25.2 (95\% confidence interval 21.2229.2), 13.0 (6.0220.0), and $3.1(0.325 .9)$ greater in switchers to simvastatin in the $\mathrm{E} / \mathrm{S}$, rosuvastatin, and atorvastatin comparisons, respectively, after adjusting for age, sex, and starting dose of the initial therapy. For switchers, the percent of patients at LDL-C , $100 \mathrm{mg} / \mathrm{dL}$ at follow-up decreased from $83.5 \%$ to $63.8 \%$ in the E/S, $67.7 \%$ to $52.7 \%$ in the rosuvastatin, and $65.1 \%$ to $60.2 \%$ in the atorvastatin cohorts. The percent of patients at LDL-C, $70 \mathrm{mg} / \mathrm{dL}$ at follow-up was lower for 
Citation: Feher A, Pusch G, Harang G, Komaromy H, Szapary L, et al. (2011) Generic Statins in Cardiovascular Medicine. J Bioequiv Availab S2. doi:10.4172/jbb.S2-003

all switcher groups compared with nonswitchers. Interestingly, hard endpoints were not analyzed in this study [37].

The IDEAL trial showed that treatment with $80 \mathrm{mg}$ atorvastatin reduced major cardiovascular events by (RR 0.87 ; $95 \%$ CI $0.77-0.98$ ) or any coronary event (RR $0.84 ; 95 \%$ CI $0.76-0.91$ ). In the prevention of cardiovascular events among patients with a previous MI, highdose atorvastatin appears to be a moderately cost-effective strategy compared with generic simvastatin 20-40 mg in Denmark, Norway, and Sweden. In Finland, it is best used in high-risk patients at current prices. The key driver of the cost-effectiveness was the price-difference between $80 \mathrm{mg}$ atorvastatin and generic simvastatin [38].

This result was confirmed by a US study based on Among 13,584 matched pairs, treatment with atorvastatin vs simvastatin was associated with a reduced risk of cardiovascular-related hospitalization, higher adherence, and less use of other lipid-lowering drugs. The increase in statin costs associated with atorvastatin vs simvastatin therapy was almost completely offset by reductions in medical service and indirect costs [39]. During the 2-year outcome period, atorvastatin vs simvastatin patients experienced significantly lower rates of total inpatient cardiovascular events $(7.5 \%$ vs $8.2 \% ; \mathrm{P}=.02)$. Treatment with atorvastatin vs simvastatin was also associated with fewer days of medically related absenteeism $(12.2$ vs $12.5 ; \mathrm{P}=.02)$ and fewer total work loss days ( 23.0 vs $23.1 ; \mathrm{P}=.04$ ), higher rates of medication adherence ( $36.3 \%$ vs $33.1 \% ; \mathrm{P}<.001)$, and lower rates of nonadherence $(11.4 \%$ vs $12.4 \%$; $\mathrm{P}<.001)$, as well as lower concomitant use of other lipid-lowering medication $(20.3 \%$ vs $24.9 \%$; $<<.001)$. As expected, pharmacy costs derived from index drug costs remained higher for atorvastatin because of the generic simvastatin ( $\$ 946$ vs $\$ 489 ; \mathrm{P}<.001$ ), but atorvastatin patients had slightly lower nonindex drug costs for all other drugs ( $\$ 1293$ vs $\$ 1315 ; P=.01$ ) and for other cardiovascularrelated drugs ( $\$ 250$ vs $\$ 275 ; P<.001$ ). Treatment with atorvastatin vs simvastatin was also associated with lower cardiovascular-related medical service costs ( $\$ 2889$ vs $\$ 3115 ; P=.02$ ), lower medically related absenteeism costs ( $\$ 2692$ vs $\$ 2798 ; P=.03$ ), and model obtained via stepwise selection, treatment with atorvastatin vs simvastatin was associated with a statistically significant $11 \%$ reduction in the hazard of cardiovascular related hospitalization (hazard ratio, 0.89; $95 \%$ confidence interval, $0.85-0.95 ; \mathrm{P}=.001$ ).

Analyzing the data of the ALLIANCE study, it also led to the same result. Medical cost offsets associated with reduced events, resulted in accepted cost-effectiveness ranges comparing atorvastatin with a generic statin. Atorvastatin-based regimens produced cost savings from a managed-care perspective when the anticipated impact of the generic availability of atorvastatin was modeled [40]

On the other hand, there is a big difference between randomized multicentre and „real-life studies”. In a two-centre London survey showed that among 1008 patients (755 who had PCI and 253 who had $\mathrm{CABG}$ ) the use of aspirin, statins, angiotensin-converting enzyme (ACE) inhibitors or angiotensin receptor blockers (ARB), beta blockers and calcium channel blockers were, respectively, 97, 98, 81, 76 and $18 \%$. The combination of any 4 classes of drug were used in $65 \%$ of patients [41]. Almost all patients who did not receive aspirin or a statin had clinical contraindications and were on alternative drugs (Figure 3 ). In about $12 \%$ of patients without an ACE inhibitor (or ARB) and $7 \%$ of

\begin{tabular}{|c|c|c|c|c|}
\hline Category of drug & $\begin{array}{l}\text { Number of } \\
\text { patients } \\
\text { not using } \\
\text { recommended } \\
\text { drug }\end{array}$ & $\begin{array}{l}\text { Reasons given for } \\
\text { not using specified drug } \\
\text { (number of patients) }\end{array}$ & $\begin{array}{l}\text { Alternative drug } \\
\text { class used } \\
\text { (number of patients) }\end{array}$ & $\begin{array}{l}\text { Number and } \\
\text { proportion of } \\
\text { cases with no } \\
\text { medical justification } \\
\text { for withholding treatment } \\
\text { and no valid alternative }\end{array}$ \\
\hline Aspirin & $32(3 \%)$ & $\begin{array}{l}\text { Gastrointestinal bleed (12) } \\
\text { Dyspepsia (6) } \\
\text { Taking warfarin (6) }^{\text {Other }}(4) \\
\text { No clinical reason }^{\text {b }}(4)\end{array}$ & $\begin{array}{l}\text { Clopidogrel (23) } \\
\text { Warfarin (8) }\end{array}$ & $1(0.1 \%)$ \\
\hline Statin & $23(2 \%)$ & $\begin{array}{l}\text { Myalgia (6) } \\
\text { Diarrhoea (8) } \\
\text { No clinical reason }{ }^{\text {b }}(9)\end{array}$ & $\begin{array}{l}\text { Ezetimibe (18) } \\
\text { Nicotinic acid (3) }\end{array}$ & $2(0.2 \%)$ \\
\hline Beta blocker & $235(23.5 \%)$ & $\begin{array}{l}\text { Asthma (79) } \\
\text { Bradycardia (9) } \\
\text { Hypotension }(15) \\
\text { Other }^{\mathrm{c}}(27) \\
\text { No clinical reason }^{\mathrm{b}}(105)\end{array}$ & $\begin{array}{l}\text { Calcium channel } \\
\text { blockers }(82)\end{array}$ & $74(7.4 \%)$ \\
\hline ACE inhibitor or ARB & $198(19.8 \%)$ & $\begin{array}{l}\text { Hypotension (20) } \\
\text { Renal impairment (11) } \\
\text { Other }^{\mathrm{d}}(18) \\
\text { No clinical reason }^{\mathrm{b}}(149)\end{array}$ & Nitrates (22) & $124(12.4 \%)$ \\
\hline
\end{tabular}

\footnotetext{
${ }^{\mathrm{a} B r o n c h o s p a s m ~(3), ~ a l l e r g y ~(1) . ~}$

b Use of recommended class of drug overlooked and no contraindication to its use.

'Patient on digoxin or amiodarone (8), intention to start treatment in primary care (8), sexual dysfunction (4), peripheral vascular disease (3), psoriasis (2), nightmares (1), aortic stenosis (1).

${ }^{d}$ Intention to start treatment in primary care (16), patient refused more medications (1), allergy (1).
}

Figure 3: Medical reasons for withholding recommended medications in 1008 patients with CHD, Taken from Ref [41] 


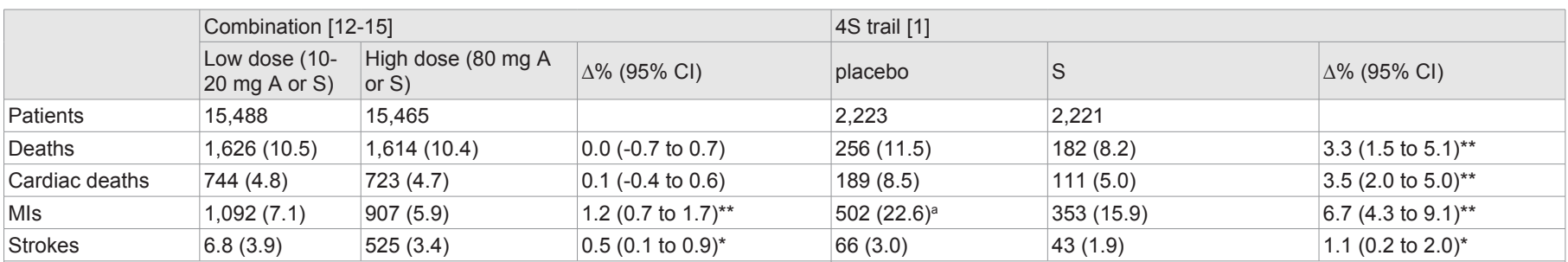

In the combination, the high-dose arm $(80 \mathrm{mg})$ is compared with the low-dose arm; in a In the $4 \mathrm{~S}$ trial, major coronary was defined as definite or probable or silent the $4 \mathrm{~S}$ trial, the drug treatment arm is compared to placebo. In parentheses beside the MI, resuscitated cardiac arrest or intervention-associated MI. This accounts, number of patients is the percent of total patients in that category. $\Delta \%$ is the percentage in part, for why there are more Mls in the 4S trial than in the TNT, IDEAL and difference in the low-dose versus high-dose arms (combination) or S arm versus placebo SEARCH trials which used less inclusive definitions. In the $4 \mathrm{~S}$ trial, if only (4S trial); the $95 \%$ confidence intervals for $\Delta \%(95 \% \mathrm{Cl})$ are shown in parentheses. ${ }^{*} p<$ definite Mls are counted, the numbers are $270(12.1 \%)$ on placebo and 164 0.05 by proportions test; ${ }^{* *} p<0.001$ by proportions test with $Z>3$. $(7.4 \%)$ on $S$ with a differential of $4.7 \%(p<0.001)$

Table 2: Comparison of the combination of the TNT, IDEAL and SEARCH with the 4S trial (Taken from Ref [42]).

patients without a beta blocker, no reason to withhold such treatment was identified. Branded drugs were used in $52 \%$ of patients; the most commonly prescribed being atorvastatin in $33 \%$. Clinical reasons for using branded rather than generic drugs were identified in $13 \%$ of cases.

So switching to a cheap, generic statin may be associated with worsening lipid profile thereby increasing the risk of unfavourable clinical outcome. To answer remaining questions about the optimal statin dose in CAD patients, Spector and Snapinn have performed simple and meta-analyses of 3 large long-term (approx. 5 years) doseclinical response studies (TNT, IDEAL, and SEARCH) and compared the results with older data including long-term safety data [42]. The results showed that raising the dose of simvastatin or atorvastatin to $80 \mathrm{mg}$ confers no mortality advantage, an increase in adverse reactions and only a slight decrease in myocardial infarctions and stroke versus a lower dose (Table 2). These results suggested a costeffective approach of a single safe dose ( $40 \mathrm{mg}$ of inexpensive generic simvastatin or atorvastatin) for almost all CAD patients and makes treatment-to-goal and cholesterol monitoring (except to check for medication compliance) unnecessary; moreover, it is likely to improve the weakness in statin use - medication compliance. So the above mentioned findings reinforce switching drugs even when showing that less potent statins were associated with worse outcomes.

\section{Final Conclusion}

The very recent ESC guidelines in the management of dyslipidaemias recommended that clinicians again should exercise judgement to avoid premature or unnecessary implementation of lipid-lowering therapy. Lifestyle interventions will have an important long-term impact on health, and the long-term effects of pharmacotherapy must be weighed against potential side effects (for example de novo diabetes) $[43,44]$. Regarding costeffectiveness and quality of life, caution is still needed in prescribing statins for primary prevention among people at low total $\mathrm{CV}$ risk. For subjects at moderate risk, an LDL-C target of $<3 \mathrm{mmol} / \mathrm{L}$ (less than $\sim 115 \mathrm{mg} / \mathrm{dL}$ ) should be considered.

Extrapolating from the available data, an absolute reduction to an LDL-C level $<1.8 \mathrm{mmol} / \mathrm{L}$ (less than $\sim 70 \mathrm{mg} / \mathrm{dL}$ ) or at least a $50 \%$ relative reduction in LDL-C provides the best benefit in terms of CVD reduction. In the majority of patients, this is achievable with statin monotherapy. Therefore, for patients with very high CV risk, the treatment target for LDL-C is, $1.8 \mathrm{mmol} / \mathrm{L}$ (less than $\sim 70 \mathrm{mg} / \mathrm{dL}$ ) or a $\geq 50 \%$ reduction from baseline LDL-C. Target levels for subjects at high risk are extrapolated from several clinical trials. An LDL-C level of $<$
$2.5 \mathrm{mmol} / \mathrm{L}$ (less than $\sim 100 \mathrm{mg} / \mathrm{dL}$ ) should be considered for them [44].

Treatment with generic statins seem to be safe and quite effective. Lipid parameters should be monitorized, there are class effects in the lipid lowering potency of different drugs (1). As previously shown, worsening lipid profile has been associated with unfavourable outcome. On the other hand, a recent meta-analysis showed the efficacy of 40 $\mathrm{mg}$ simvastatin or $40 \mathrm{mg}$ atorvastatin in secondary prevention trials. So the above mentioned findings reinforce switching drugs even when showing that less potent statins were associated with worse outcomes.

In general, from an economic point of view, society could gain a lot from substituting statin therapy, especially from therapeutic substitution [29]. Moreover, prescribing generic or preferred medications within a therapeutic class was associated with improvements in adherence to therapy [30]. Switching the brand statin to an equivalent dose of generic statin (maybe from another class) can be associated with no change in lipid control [31].

Patients' global risk and underlying diseases should also be considered. There are primary and secondary prevention problems worldwide [45-48].

\section{References}

1. Feher A, Pusch G, Koltai K, Tibold A, Gasztonyi B, et al. (2011) Statintherapy in the primary and the secondary prevention of ischaemic cerebrovascular diseases. Int J Cardiol. 148: 131-138.

2. Greving JP, Visseren FL, de Wit GA, Algra A (2011) Primary prevention with statins: for whom is it cost-effective? Ned Tijdschr Geneeskd 155: A3411.

3. Seabra-Gomes R (2007) The paradigm of stains: will the lower cost of generics translate into health gains? Rev Port Cardiol 26: 497-501

4. Graham I, Atar D, Borch-Johnsen K, Boysen G, Burell G, et al. (2007) European guidelines on cardiovascular disease prevention in clinical practice: executive summary. Atherosclerosis 194:1-45

5. Fischer MA, Avorn J (2004) Potential savings from increased use of generic drugs in the elderly: what the experience of Medicaid and other insurance programs means for a Medicare drug benefit.. Pharmacoepidemiol Drug Saf 13: $207-214$

6. Shrank WH, Hoang T, Ettner SL, Glassman PA, Nair K, et al. (2006) The implications of choice: prescribing generic or preferred pharmaceuticals improves medication adherence for chronic conditions. Arch Intern Med 166 332-337.

7. Goldman DP, Joyce GF, Zheng Y(2007) Prescription drug cost sharing associations with medication and medical utilization and spending and health JAMA 298: 61-69. 
Citation: Feher A, Pusch G, Harang G, Komaromy H, Szapary L, et al. (2011) Generic Statins in Cardiovascular Medicine. J Bioequiv Availab S2. doi:10.4172/jbb.S2-003

8. Kesselheim AS, Misono AS, Lee JL, Stedman MR, Brookhart MA, et al. (2008) Clinical equivalence of generic and brand-name drugs used in cardiovascular disease: a systematic review and meta-analysis. JAMA 300: 2514-26.

9. Vrecer M, Turk S, Drinovec J, Mrhar A (2003) Use of statins in primary and secondary prevention of coronary heart disease and ischemic stroke. Metaanalysis of randomized trials. Int J Clin Pharmacol Ther 41: 567-77.

10. Thavendiranathan P, Bagai A, Brookhart MA, Choudhry NK (2006) Primary prevention of cardiovascular diseases with statin therapy: a meta-analysis of randomized controlled trials. Arch Intern Med 166: 2307-2313.

11. Ward S, Lloyd Jones M, Pandor A, Holmes M, Ara R, et al. (2007) A systematic review and economic evaluation of statins for the prevention of coronary events. Health Technol Assess 11: 1-160.

12. Mills EJ, Rachlis B, Wu P, Devereaux PJ, Arora P, et al. (2008) Primary prevention of cardiovascular mortality and events with statin treatments: a network meta-analysis involving more than 65, 000 patients. J Am Coll Cardio 52: $1769-1781$

13. Taylor F, Ward K, Moore TH, Burke M, Davey Smith G, et al. (2001) Statins for the primary prevention of cardiovascular disease. Cochrane Database Syst Rev CD004816.

14. Ray KK, Seshasai SR, Erqou S, Sever P, Jukema JW, et al. (2010) Statins and all-cause mortality in high-risk primary prevention: a meta-analysis of 11 randomized controlled trials involving 65,229 participants. Arch Intern Med 170 1024-1031.

15. Greving JP, Visseren FL, de Wit GA, Algra A (2011) Statin treatment for primary prevention of vascular disease: whom to treat? Cost-effectiveness analysis. BMJ 342:d1672.

16. Delahoy PJ, Magliano DJ, Webb K, Grobler M, Liew D (2009) The relationship between reduction in low-density lipoprotein cholesterol by statins and reduction in risk of cardiovascular outcomes: an updated meta-analysis. Clin Ther 31: 236-244.

17. Kang HY, Ko SK, Liew D (2009) Results of a Markov model analysis to assess the cost-effectiveness of statin therapy for the primary prevention of cardiovascular disease in Korea: the Korean Individual-Microsimulation Model for Cardiovascular Health Interventions. Clin Ther 31: 2919-2930.

18. Brugts JJ, Yetgin T, Hoeks SE, Gotto AM, Shepherd J, et al. (2009) The benefits of statins in people without established cardiovascular disease but with cardiovascular risk factors: meta-analysis of randomised controlled trials. BM 338:b2376

19. Grammer TB, Maerz W (2011) Are statins really useless in "primary prevention"? Recent Cochrane meta-analysis revisited. Int J Clin Pharmacol Ther 49: 293296.

20. Cholesterol Treatment Trialists' (CTT) Collaboration, Baigent C, Blackwell L, Emberson J, Holland LE, et al. (2010) Efficacy and safety of more intensive lowering of LDL cholesterol: a meta-analysis of data from 170,000 participants in 26 randomised trials. Lancet 376: 1670-81.

21. Wiwanitkit V, Wangsaturaka D, Tangphao O (2002) LDL-cholesterol lowering effect of a generic product of simvastatin compared to simvastatin (Zocor) in Thai hypercholesterolemic subjects -- a randomized crossover study, the first report from Thailand. BMC Clin Pharmacol 2: 1.

22. Assawawitoontip S, Wiwanitkit V (2002) A randomized crossover study to evaluate LDL-cholesterol lowering effect of a generic product of simvastatin (Unison Company) compared to simvastatin (Zocor) in hypercholesterolemic subjects. J Med Assoc Thai 85: S118-124.

23. Kim SH, Park K, Hong SJ, Cho YS, Sung JD, et al. (2010) Efficacy and tolerability of a generic and a branded formulation of atorvastatin $20 \mathrm{mg} / \mathrm{d}$ in hypercholesterolemic Korean adults at high risk for cardiovascular disease: a multicenter, prospective, randomized, double-blind, double-dummy clinical trial. Clin Ther 32: 1896-1905.

24. Liu YM, Pu HH, Liu GY, Jia JY, Weng LP, et al. (2010) Pharmacokinetics and bioequivalence evaluation of two different atorvastatin calcium 10-mg tablets: A single-dose, randomized-sequence, open-label, two-period crossover study in healthy fasted Chinese adult males. Clin Ther 32: 1396-407.
25. Lachaine J, Merikle E, Tarride JE, Montpetit M, Rinfret S (2007) A model for assessing the cost-effectiveness of atorvastatin and simvastatin in achieving Canadian low-density lipoprotein cholesterol targets. Clin Ther 29: 519-28.

26. Costa-Scharplatz M, Ramanathan K, Frial T, Beamer B, Gandhi S (2008) Costeffectiveness analysis of rosuvastatin versus atorvastatin, simvastatin, and pravastatin from a Canadian health system perspective. Clin Ther 30: 1345-57.

27. Ward S, Lloyd Jones M, Pandor A, Holmes M, Ara R, et al. (2007) A systematic review and economic evaluation of statins for the prevention of coronary events. Health Technol Assess 11:1-160.

28. Tran YB, Frial T, Miller PS (2007) Statin's cost-effectiveness: a Canadian analysis of commonly prescribed generic and brand name statins. Can J Clin Pharmacol 14: e205-14.

29. Gumbs PD, Verschuren WM, Souverein PC, Mantel-Teeuwisse AK, de Wi GA, et al. (2007) Society already achieves economic benefits from generic substitution but fails to do the same for therapeutic substitution. $\mathrm{Br} \mathrm{J} \mathrm{Clin}$ Pharmacol 64: 680-5.

30. Shrank WH, Hoang T, Ettner SL, Glassman PA, Nair K, et al. (2006) The implications of choice: prescribing generic or preferred pharmaceuticals improves medication adherence for chronic conditions. Arch Intern Med 166 $332-7$.

31. Billups SJ, Plushner SL, Olson KL, Koehler TJ, Kerzee J (2005) Clinical and economic outcomes of conversion of simvastatin to lovastatin in a group-mode health maintenance organization. J Manag Care Pharm 11: 681-6.

32. Heart Protection Study Collaborative Group (2009) Statin cost-effectiveness in the United States for people at different vascular risk levels. Circ Cardiovasc Qual Outcomes 2: 65-72.

33. Aung PP, Maxwell HG, Jepson RG, Price JF, Leng GC (2007) Lipid-lowering for peripheral arterial disease of the lower limb. Cochrane Database Syst Rev CD000123.

34. Momsen AH, Jensen MB, Norager CB, Madsen MR, Vestersgaard-Andersen $\mathrm{T}$, et al. (2009) Drug therapy for improving walking distance in intermittent claudication: a systematic review and meta-analysis of robust randomised controlled studies. Eur J Vasc Endovasc Surg 38: 463-74.

35. Amarenco P, Labreuche J (2009) Lipid management in the prevention of stroke: review and updated meta-analysis of statins for stroke prevention. Lancet Neurol 8: 453-63.

36. Mills EJ, Wu P, Chong G, Ghement I, Singh S, et al. (2001) Efficacy and safety of statin treatment for cardiovascular disease: a network meta-analysis of 170,255 patients from 76 randomized trials. QJM 104: 109-24.

37. Tunceli K, Sajjan SG, Ramey DR, Neff DR, Tershakovec AM, et al. (2010) Switching from high-efficacy lipid-lowering therapies to simvastatin and low density lipoprotein cholesterol goal attainment in coronary heart disease/ coronary heart disease-equivalent patients. J Clin Lipidol 4: 491-500.

38. Lindgren P, Graff J, Olsson AG, Pedersen TJ, Jönsson B (2007) Costeffectiveness of high-dose atorvastatin compared with regular dose simvastatin. Eur Heart J 28: 1448-53.

39. Simpson RJ Jr, Signorovitch J, Birnbaum H, Ivanova J, Connolly C, et al. (2009) Cardiovascular and economic outcomes after initiation of lipid-lowering therapy with atorvastatin vs simvastatin in an employed population. Mayo Clin Proc 84: 1065-72.

40. Mullins CD, Rattinger GB, Kuznik A, Koren MJ (2008) Cost-effectiveness of intensive atorvastatin treatment in high-risk patients compared with usual care in a postgeneric statin market: economic analysis of the Aggressive Lipidlowering Initiation Abates New Cardiac Events (ALLIANCE) study. Clin Ther 2 2204-16.

41. Corp EV, Antoniou S, Wright PG, Khachi H, Vercaeren S, et al. (2009) Use and cost of branded and generic drugs in patients with coronary heart disease-results from a prospective survey of 1008 patients in two London hospitals. QJM 102: 843-9

42. Spector R, Snapinn SM (2001) Statins for secondary prevention of cardiovascular disease: the right dose. Pharmacology 87: 63-9. 
Citation: Feher A, Pusch G, Harang G, Komaromy H, Szapary L, et al. (2011) Generic Statins in Cardiovascular Medicine. J Bioequiv Availab S2. doi:10.4172/jbb.S2-003

Page 8 of 8

43. Preiss D, Seshasai SR, Welsh P, Murphy SA, Ho JE, et al. (2011) Risk of incident diabetes with intensive-dose compared with moderate-dose statin therapy: a meta-analysis. JAMA 305: 2556-64.

44. European Association for Cardiovascular Prevention \& Rehabilitation, Reiner Z, Catapano AL, De Backer G, Graham I, et al. (2011) ESC/EAS Guidelines for the management of dyslipidaemias: the Task Force for the management of dyslipidaemias of the European Society of Cardiology (ESC) and the European Atherosclerosis Society (EAS). Eur Heart J 32: 1769-818.

45. Galuscan G, Georges JL, Gardenat-Leboidre S, Gibault-Genty G, Stefas L, et al. (2008) Secondary prevention after acute coronary syndrome: therapeutic goals achievement in relation with changes in guidelines. Ann Cardiol Angeiol 57: 268-74.

46. Völler H, Reibis R, Pittrow D, Jannowitz C, Wegscheider K, et al. (2009) Secondary prevention of diabetic patients with coronary artery disease in cardiac rehabilitation: risk factors, treatment and target level attainment. Curr Med Res Opin 25: 879-90.

47. Feher A, Pusch G, Harang G, Gasztonyi B, Papp E, et al. (2011) Aspirin resistance in cerebrovascular patients. Int J Cardiol 152:111-2.

48. Feher G, Feher A, Pusch G, Koltai K, Tibold A, et al. (2010) Clinical importance of aspirin and clopidogrel resistance. World J Cardiol 2: 171-86. 